\title{
APOB Gene
}

National Cancer Institute

\section{Source}

National Cancer Institute. APOB Gene. NCI Thesaurus. Code C106030.

This gene plays a role in lipid transport. 